038

\section{PRECLINICAL AND CLINICAL CHARACTERIZATION OF CENERIMOD, A POTENT, SELECTIVE, AND ORALLY ACTIVE SPHINGOSINE-1-PHOSPHATE RECEPTOR 1 MODULATOR IN SLE}

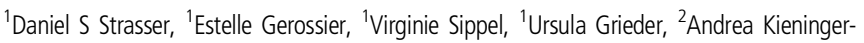
Graefitsch, ' ${ }^{1}$ Gabin Pierlot, ${ }^{1}$ Hervé Farine, ${ }^{1}$ Paulina Kulig, 'Marcel Keller, 'Sylvie Froidevaux, ${ }^{2}$ Marten Trendelenburg, 'Mark Murphy, 'Marianne Martinic. 'Idorsia Pharmaceuticals Ltd, Allschwil; ${ }^{2}$ Division of Internal Medicine and Clinical Immunology, University Hospital Basel, Basel, Switzerland

\subsection{6/lupus-2020-eurolupus.49}

Background Reported here is the characterization of cenerimod, a novel, potent, selective, and orally active sphingosine1-phosphate receptor $1\left(\mathrm{~S}_{1} \mathrm{P}_{1}\right)$ modulator in the context of SLE.

Methods Lymphocytes from patients with SLE and healthy subjects were assessed for cenerimod-induced $\mathrm{S}_{1} \mathrm{P}_{1}$ receptor internalization. Efficacy of cenerimod was evaluated in the MRL/lpr lupus mouse model. In a 12 -week phase 2 clinical trial in SLE subjects treated with multiple doses of cenerimod (NCT02472795), lymphocyte subsets and inflammatory biomarkers were characterized.

Results Cenerimod was potent and efficacious at inducing $\mathrm{S}_{1} \mathrm{P}_{1}$ receptor internalization in $\mathrm{T}$ and $\mathrm{B}$ lymphocytes with an $\mathrm{EC}_{50}$ of $\sim 15 \mathrm{nM}$ in both healthy subjects and patients with SLE. In lupus-like MRL/lpr mice treated with cenerimod, circulating $\mathrm{T}$ and $\mathrm{B}$ lymphocytes were reduced, which resulted in reduced immune infiltrates into tissue, reduced autoantibody production and inflammation, preserved organ function, and increased survival. In SLE subjects treated with cenerimod for 12 weeks, a dose-dependent reduction of circulating $\mathrm{T}$ cells (95\%), B cells (90\%), and antibody-secreting cells $(85 \%)$ was evident. Furthermore, a reduction in anti-dsDNA antibodies and IFN- $\alpha$, two key inflammatory molecules, was observed.

Conclusion Cenerimod was potent and efficacious in reducing $\mathrm{S}_{1} \mathrm{P}_{1}$ receptor surface expression on lymphocytes, resulting in reduced circulating $\mathrm{T}$ and $\mathrm{B}$ lymphocyte populations, including antibody-secreting cells, and a decrease in inflammatory biomarkers in SLE subjects. Furthermore, cenerimod significantly ameliorated systemic and organ-specific autoimmunity in a mouse model of SLE. These results warranted the further investigation of the clinical efficacy and safety of cenerimod in the ongoing phase 2b clinical trial (NCT03742037).

Acknowledgments This research was funded by Idorsia Pharmaceuticals Ltd.

\section{Poster presentations}

\section{P1 ANTIPHOSPHOLIPID SYNDROME IN QATAR: EPIDEMIOLOGICAL, CLINICAL, AND IMMUNOLOGICAL CHARACTERISTICS}

Nabeel Abdulla, Omar Alsaed, Fiaz Alam, Rawan Saleh, Abdulrazzakh Poil, Abdelrahim Siam, Eman Elsayed, Hani Abdulaziz, Samar Al Emadi. Rheumatology Division, Hamad Medical Corporation, Doha, Qatar

10.1136/lupus-2020-eurolupus.50

Purpose The aim of this study is to analyze epidemiological, clinical, and immunologic characteristics of primary and secondary antiphospholipid syndrome (APS) cases in Qatar.
Methods All patients with primary and secondary APS attending rheumatology clinics from January 2017 to May 2019 at Hamad General Hospital were identified and medical records were retrospectively reviewed.

Results 131 patients with APS who fulfilled revised Sapporo APS classification criteria were included- 116 women $(88.5 \%)$ and 15 men (11.5\%). 79 patients $(60.3 \%)$ had primary and 52 patients (39.7\%) had secondary APS. 41 patients $(31.3 \%)$ had thrombotic event only, 64 patients $(48.9 \%)$ had pregnancy morbidity only, and 26 patients $(19.8 \%)$ had both thrombosis as well as pregnancy morbidity. 7 patients $(5.4 \%)$ had arterial thrombosis only, 48 patients $(36.6 \%)$ had venous thrombosis only and 12 patients (9.1\%) had both arterial and venous thrombosis. $103(78.6 \%)$ patients had pregnancy morbidity out of the 116 female patients. Early fetal loss was the commonest pregnancy morbidity seen in 73 patients $(70.9 \%)$, followed by late fetal loss in 57 patients $(55.3 \%)$.

48 patients $(36.6 \%)$ had aCL IgG positive and 15 patients $(11.5 \%)$ had aCL IgM positive, either one was positive in 54 patients (41.2\%). 42 patients (32.1\%) had B2GP IgG positive and 19 patients (14.5\%) had B2GP IgM positive, either one was positive in 53 patients $(40.7 \%)$. LA was positive in 121 patients $(92.4 \%)$. There were 71 patients $(54.2 \%)$ with single positive aPL test, 21 patients $(16 \%)$ with double positive and 37 patients $(28.2 \%)$ with triple positive aPL test results. LA was the most common single positive aPL test, seen in 65 patients $(50.3 \%)$

Conclusion The clinical manifestation and immunological characteristics of patients with APS in Qatar are diverse. Our cohort has much higher prevalence of LA positivity compared to other cohorts around the world. We also have a higher incidence of pregnancy morbidities.

Acknowledgements Study funded by Medical research center at Hamad Medical Corporation.

\section{P2 DIFFICULTIES IN MANAGING A PATIENT WITH MULTI-ORGAN DAMAGE IN SYSTEMIC LUPUS ERYTHEMATOSUS AND A HIGH RISK OF THROMBOTIC EVENTS IN ANTIPHOSPHOLIPID SYNDROME (CASE REPORT)}

\begin{abstract}
${ }^{1,2}$ Fariza Cheldieva, ${ }^{1,2}$ Tatiana Reshetnyak, ${ }^{1}$ Anastasiia Shumilova, ${ }^{1}$ Natalia Seredavkina ${ }^{1}$ Maria Cherkasova, ${ }^{1}$ Tatiana Lisitsyna, ${ }^{3}$ Anastasia Borisova, ${ }^{1,2}$ Alexander Lila. ${ }^{1}$ Federal State Budgetary Scientific Institution 'Research Institute of Rheumatology named after V.A. Nasonova', Moscow; 'Federal State Budgetary Educational Institution of Further Professional Education 'Russian Medical Academy of Continuous Professional Education' of the Ministry of Healthcare of the Russian Federation, Rheumatology Academic Dept. Moscow; ${ }^{3}$ Moscow Research Institute of Psychiatry, Serbsky NMRC PN MoH, Moscow, Russian Federation
\end{abstract}

\subsection{6/lupus-2020-eurolupus.51}

Background Systemic lupus erythematosus (SLE) is a multisystem disease with many clinical manifestations. Late diagnosis, kidney damage, neuropsychiatric disorders, high risk of thrombotic events, resistance to therapy worsen the prognosis of the disease and increase mortality.

Methods Description of a clinical case of multiple organ damages in a patient with SLE and concomitant antiphospholipid syndrome (APS).

Results We describe a case report of organ damage in a patient with SLE and concomitant APS. The clinical and laboratory manifestations for the entire period of the disease are given below (table 1). Now the main manifestation of the disease in 
Abstract P2 Table 1 The clinical and laboratory manifestations for the entire period of the disease

\begin{tabular}{|c|c|c|c|c|c|c|c|c|c|c|}
\hline$\underbrace{\text { Age }}_{\text {Manifestations }}$ & $\begin{array}{l}16 \text { years } \\
\text { old, } 2000\end{array}$ & $\begin{array}{l}17 \text { years } \\
\text { old, } 2001\end{array}$ & $\begin{array}{l}21 \text { years } \\
\text { old, } 2005\end{array}$ & $\begin{array}{l}25 \text { years } \\
\text { old, } 2009\end{array}$ & $\begin{array}{c}26 \text { years old, } \\
2010\end{array}$ & $\begin{array}{l}28 \text { years } \\
\text { old, } 2012\end{array}$ & $\begin{array}{c}30 \text { years old, } \\
2014\end{array}$ & $\begin{array}{c}\text { 31-21 years } \\
\text { old, 2015-2016 }\end{array}$ & $\begin{array}{l}35 \text { years } \\
\text { old, } 2018\end{array}$ & $\begin{array}{c}36 \text { years old, } \\
2019\end{array}$ \\
\hline Arthritis/arthrs/gia & & \multicolumn{2}{|c|}{ knee joints } & $\begin{array}{l}\text { joints of the } \\
\text { hands. } \\
\text { knee joints }\end{array}$ & & & $\begin{array}{l}\text { wrist joints, } \\
\text { knee joints }\end{array}$ & & & \\
\hline Thrombosis & DVLL & DVLL, SVLL & & & & & & & & DVLL \\
\hline Proteinuria (g/dgy) & & & & & & $v$ & 0.2 & $\checkmark$ & $\checkmark$ & 1.700 \\
\hline $\begin{array}{l}\text { Change in urinary } \\
\text { sediment }\end{array}$ & & & & & $\checkmark$ & $\checkmark$ & $r$ & $\checkmark$ & $\checkmark$ & $\checkmark$ \\
\hline Fever, erythems & & & & & $\checkmark$ & & & & & \\
\hline Pericarditis, pleuritis & & & & & & & $\checkmark$ & & & \\
\hline $\begin{array}{l}\text { Kidney Biopsy- } \\
\text { Grsde IVC (A) } \\
\text { Glomerulonephritis }\end{array}$ & & & & & & $\begin{array}{l}\mathrm{Al}-8, \\
\mathrm{Cl}-2\end{array}$ & & & & \\
\hline $\begin{array}{l}\text { Bleeding after a } \\
\text { kidney biopsy - } \\
\text { Nephrectomy }\end{array}$ & & & & & & $\boldsymbol{r}$ & & & & \\
\hline $\begin{array}{l}\text { Epilepsy. MRI- } \\
\text { changes in the brain }\end{array}$ & & & & & & & & $\checkmark$ & $\checkmark$ & $\checkmark$ \\
\hline Antinuclegr factor & & & & & & $v$ & $\checkmark$ & $v$ & $\checkmark$ & $1 / 320$ \\
\hline At-ds-DNA (IU/ml) & & & & & $>200$ & $\checkmark$ & $>300$ & $\checkmark$ & 257.9 & $>200,0$ \\
\hline Smith sntigen & & & & & $\checkmark$ & & & & & \\
\hline $\begin{array}{l}\lg G \text { aKL (GPL) / /gM } \\
\text { gKL (MPL) }\end{array}$ & & & & & $>190$ & $\checkmark$ & $>120$ & $\checkmark$ & $>120 />80$ & $>120 / 49.8$ \\
\hline $\begin{array}{l}\operatorname{lgG} \text { a } 2 \text { GP1 (U/ml) / } \\
\operatorname{lgM} \text { a } 32 \mathrm{GP} 1(\mathrm{U} / \mathrm{ml})\end{array}$ & & & & & $>100$ & $\checkmark$ & $>100$ & $\checkmark$ & $>100 />100$ & $>100 / 41$ \\
\hline Hypocomplementemis & & & & & & & $\checkmark$ & $\checkmark$ & $\checkmark$ & $\checkmark$ \\
\hline Diagnosis & $\begin{array}{c}\text { Acute } \\
\text { thrombosis }\end{array}$ & $\begin{array}{c}\text { Reactive } \\
\text { arthritis }\end{array}$ & $\begin{array}{c}\text { Reactive } \\
\text { arthritis }\end{array}$ & $\begin{array}{c}\text { Reactive } \\
\text { grthritis }\end{array}$ & SLE, APS & SLE, APS & SLE, APS & SLE, APS & SLE, APS & SLE, APS \\
\hline Treatment tsctics & & $\begin{array}{l}\text { NSAID, } \\
\text { Antibiotic } \\
\text { therapy }\end{array}$ & $\begin{array}{l}\text { NSAID. } \\
\text { Antibiotic } \\
\text { therapy }\end{array}$ & $\begin{array}{l}\text { Sulfasalgzi- } \\
\text { ne } 2 \text { g/dsy } \\
\text { (7 month) }\end{array}$ & $\begin{array}{c}\text { Prednisolone } \\
20 \text { mg/day (5 } \\
\text { month) } \rightarrow 4 \\
\text { mg/day. } \\
\text { Azathioprine } \\
100 \text { mg/day (3 } \\
\text { month) } \\
\text { Hydroxychlo- } \\
\text { rochine } 200 \\
\text { mg/day (3 } \\
\text { month) }\end{array}$ & $\begin{array}{c}\text { Methylpred- } \\
\text { nisolone } 60 \\
\rightarrow 4 \text { mg/dsy. } \\
\text { Human } \\
\text { Immunoglo- } \\
\text { bulin, } \\
\text { Warfgrin } \\
\text { (without } \\
\text { control INR) }\end{array}$ & $\begin{array}{l}\text { Methylpredni- } \\
\text { solone } 16 \\
\text { mg/dsy. } \\
\text { Hydroxychlo- } \\
\text { rochine } 200 \\
\text { mg/dsy. } \\
\text { Warfarin } \\
\text { (without } \\
\text { control INR) }\end{array}$ & $\begin{array}{l}\text { Methyloredoisa- } \\
\text { lone } 4 \text { mg/day. } \\
\text { Hxocosychloce- } \\
\text { chine } 200 \\
\text { mg/day. } \\
\text { Dabigatran } \\
\text { etexilste } 300 \\
\text { mg/daghr } \\
\text { Warfarin (INR } \\
>2 \text { ). } \\
\text { Acidi valproici }\end{array}$ & $\begin{array}{c}\text { Methylpred- } \\
\text { nisolone } 4 \\
\text { mg/day. } \\
\text { Hydroxychlo- } \\
\text { rochine 200 } \\
\text { mg/day. } \\
\text { Rivaroxabsn } \\
20 \text { mg/day. } \\
\text { Acidi } \\
\text { valproici }\end{array}$ & $\begin{array}{c}\text { Rituximab } 1000 \\
\text { g. } \\
\text { Methylpredniso- } \\
\text { lone } 16 \text { mg/dsy. } \\
\text { Hydroxychloro- } \\
\text { chine } 200 \\
\text { mg/dsy } \\
\text { Rivaroxsban } 20 \\
\text { mg/day } \rightarrow \\
\text { Nadropgrin } \\
\text { calcium } 0.6 / d 9 y \\
\rightarrow \text { Apicaban } 10 \\
\text { mg/day. } \\
\text { Acidi valoroici }\end{array}$ \\
\hline
\end{tabular}

-OVLL - deep veins lower leg. SVLL - superficigl veins lower leg. Al - gctivity index, CI - chronicity index, SLE - systemic lupus erythematosus, APS - antiphospholipid syndrome, NSAID - nonsteroidgl anti-inflammstory drugs, INR - internstionsl norms lized ratio

clinical finding are: active lupus nephritis of a kidney, relapse of venous thrombosis as a result of APS, thrombotic microangioencephalopathy, cognitive impairment and somatogenic asthenodepressive syndrome.

Conclusions This clinical case demonstrates a patient with SLE presented in clinical features thrombosis, lupus glomerulonephritis class IV, AI 8, CI 2, high immunological disorders and concomitant APS. The difficulty in treating the patient is the consistently high immunological activity of the disease, the resistance of the therapy cytostatic and glucocorticoids, the inefficiency and intolerance of a number of oral anticoagulants: dabigatran etexilate and rivaroxaban - relapses of thrombosis, warfarin - the inability to reach the target levels of the international normalized ratio (INR) due to recurrent nosebleeds.

\section{P3 IS THERE A RELATIONSHIP BETWEEN LUPUS ANTICOAGULANT AUTOANTIBODY AND FATIGUE IN JSLE?}

${ }^{1}$ Sara Ganhão, ${ }^{2}$ Beatriz Silva, ${ }^{1}$ Mariana Rodrigues, ${ }^{1}$ Francisca Aguiar, 2,3 Margarida Figueiredo-Braga, ${ }^{1,2}$ Iva Brito. ${ }^{1}$ Young Adult and Pediatric Rheumatology Unit, Centro Hospitalar e Universitário do Hospital de São João, Porto; ${ }^{2}$ Faculty of Medicine, University of Porto, Porto; ${ }^{3}$ Dept. of Clinical Neurosciences and Mental Health, Porto, Portugal

10.1136/lupus-2020-eurolupus.52

Background Fatigue is a common symptom in systemic lupus erythematosus (SLE) and is associated with poorer quality of life and higher depression scores. Lupus anticoagulant (AcL) refers to a subset of autoantibodies to phospholipids interfering with clotting tests, which major clinical association is thrombosis. Physical activity reduces thrombotic risk in general and is a potential therapeutic strategy for managing fatigue in SLE patients. Purpose: To compare fatigue outcomes according to AcL status in juvenile-onset SLE (jSLE).

Methods A cross-sectional sample of jSLE patients, currently aged $\geq 16$ years, completed SF-36, HADS and FSS questionnaires between October 2018- May 2019. The study was approved by the local Ethics Committee. All patients fulfilled both 2012 and 2019 EULAR/ACR classification criteria for SLE. Juvenile-onset was defined as age at diagnosis $<18$ years. Demographics and clinical characteristics were collected. Statistical analysis was performed with SPSS ${ }^{\circledR}$.

Results jSLE patients $(n=30)$ were studied (90\%female) with median age of 21 years, range 16-35, with mean (SD) age of diagnosis of $15.8 \pm 2.1$. Mean values (SD) of psychological assessment were: FSS $4.27 \pm 1.36$; Physical health SF36 of $66.8(9.9)$ and Mental health SF-36 of 68.9 (17.5). $56.7 \%$ jSLE showed clinically relevant fatigue, $63.3 \%$ anxiety and $13.3 \%$ depression. Four patients (13.3\%) had positive AcL autoantibody. Those had lower Fatigue Severity Scale (FSS) average scores: $3.0(0.16)$ vs $4.5(0.28)$, comparing to those who were negative for AcL $(p=0.036)$. Likewise, positive AcL jSLE patients had better results in SF-36 Physical Health questionnaires $(p=0.034)$.

Conclusions The relationship between AcL status and fatigue was not previously known. We hypothesize that the present finding may be related to physical activity, a major indication 